ZalǫcZnilf

DOI 10.21697/zk.2021.8.14

\title{
BRUNO SCHULZ W UMARŁEJ KLASIE TADEUSZA KANTORA. REALNOŚĆ ARTYSTYCZNA I KONEKSJE LITERACKIE
}

Katarzyna Flader-Rzeszowska

\author{
Wydział Nauk Teologicznych UKSW \\ Faculty of Theology \\ Cardinal Stefan Wyszyński University in Warsaw \\ katarzyna.flader@wp.pl \\ ORCID: 0000-0002-4110-9788
}

Lista młodzieńczych lektur Tadeusza Kantora z lat 1938-1940 jest długa i różnorodna ${ }^{1}$. Znajdują się na niej twórcy polscy i europejscy żyjący na przełomie XIX i XX wieku. Obok symbolistów są przedstawiciele realizmu, przy dramatopisarzach - filozofowie. Nie zabrakło Tołstoja, Dostojewskiego, Shawa, Prousta, Micińskiego, Zegadłowicza, ale i Maritaina, Claudela, Chestertona czy Bernanosa. W rozmowie z Wiesławem Borowskim, wspominając okres okupacji, Kantor wymieniał jeszcze innych twórców: „ugruntowałem swoje lektury takich pisarzy, jak: Maeterlinck, Wyspiański, Kafka, Gombrowicz, Schulz, no i Witkiewicz"2. Jak podkreślał, jego pokolenie dorastało w cieniu autora Sklepów cynamonowych.

\section{KLASYCY WSPÓŁCZESNOŚCI}

W 1978 roku w tekście Moja droga do Teatru Śmierci, wygłoszonym na spotkaniu z Sekcją Krytyki Dziennikarzy Polskich w Warszawie, Tadeusz Kantor wspominał, że Witkacy, Schulz i Gombrowicz byli trzema pisarzami ważnymi dla jego generacji ${ }^{3}$. O jego uznaniu dla Witkacego-pisarza

1 Zob. Tadeusz Kantor. Wędrówka, red. J. Chrobak, L. Stangret, M. Świca, Kraków 2000, s. 25.

2 W. Borowski, Tadeusz Kantor, Warszawa 1982, s. 22.

3 T. Kantor, Moja droga do Teatru Śmierci, [w:] idem, Teatr Śmierci. Teksty z lat 1975-1984, Pisma, t. II, wybór i oprac. K. Pleśniarowicz, Kraków-Wrocław 2004, s. 456457. Zbigniew Osiński podkreślał zwłaszcza wpływ Gombrowicza, dowodził, że Kantor 
(bo nie malarza) świadczy niewątpliwie fakt, że teatr Cricot 2 od dramatu tego autora rozpoczął swoją ponaddwudziestoletnią grę z Witkacym. Cenił Witkacego i Gombrowicza m.in. za piętnowanie „potworności wszelkiego filisterstwa mieszczańskiego"4. Znana jest doskonale metoda dwutorowości, według której Kantor wystawiał kolejne Witkacowskie tytuły. Uważał, że akcja sztuki (tor dramatu) musi toczyć się niezależnie od działań scenicznych (tor spektaklu). Te dwie realności musiały być odległe, by teatr nie stał się miejscem wystawiania, „reprodukowania” literatury, lecz był przestrzenią kreacji. Kantor ze swoim zespołem przygotował: Mątwę, W małym dworku, Wariata i zakonnice, Kurkę wodna, Nadobnisie i koczkodany oraz fragmenty Tumora Mózgowicza.

O wystawieniu dramatu Gombrowicza Kantor myślał w drugiej połowie lat pięćdziesiątych. W liście z 1957 roku do współzałożycielki Crioctu - Marii Jaremy, przebywającej wówczas w Paryżu, donosił:

Marysiu! Przesyłam programy i pocztówki - Cricot idzie - oczywiście duże kłopoty finansowe - jak to się skończy, nie wiem. Kine-formy Pawłowskiego wzbudzają bardzo duże zainteresowanie. Tekst Mikulskiego jest jednak zbyt komunikatywny - robimy szybko Iwonę [Księżniczkę Burgunda Gombrowicza - przyp. K.F-R.] - koncepcji jeszcze oczywiście nie mam. Trzeba ją oprzeć na skandalu - nasze społeczeństwo rozwydrzyło się - już nie chce niczego, co by było normalne i zdrowe - wnet zabraknie pomysłów dla zaspokojenia tej hydry ${ }^{5}$.

W roku 1958 - jak podaje Krzysztof Pleśniarowicz - Kantor pisał do Gombrowicza, że Iwona „pójdzie w Cricocie” i dalej: „za wiele przemyślałem nad Iwona... abym miał jej nie zrealizować”6. A jednak, jak pokaże

wręcz fascynował się twórczością autora Ferdydurke. Zob. Z. Osiński, Tadeusz Kantor Jerzy Grotowski: dwie idee teatru/sztuki, [w:] Dziś Tadeusz Kantor. Metamorfozy śmierci, pamięci i obecności, red. M. Bryś, A.R. Burzyńska, K. Fazan, Kraków 2014, s. 362.

4 T. Kantor, Aneks. Kraków: Cricot II, [w:] idem, Dalej już nic... Teksty z lat 19851990, Pisma, tom III, wybór i oprac. K. Pleśniarowicz, Kraków-Wrocław 2005, s. 358.

5 List Tadeusza Kantora do Marii Jaremy, cyt. za: A. Dauksza, Jaremianka, Kraków 2019, s. 529.

${ }^{6}$ List Tadeusza Kantora do Witolda Gombrowicza, cyt. za: K. Pleśniarowicz, Kantor, Warszawa 2018, s. 127. 
historia, nie udało mu się wystawić dramatu. Kantor nie otrzymał na to zgody od samego autora. Z niezrealizowanej inscenizacji pozostały projekty scenograficzne, które zilustrowały pierwsze polskie wydanie dramatu w Państwowym Instytucie Wydawniczym w 1958 roku. Gombrowicz nie był nimi zachwycony. W jednym z listów do Alicji Giangrande - swojej przyjaciółki, malarki - pisał: „plastycy mszczą się za moje bluźnierstwa i już przypuścili atak na moją Iwonę"7.

Kantor nigdy nie „zagrał” z Gombrowiczem tak, jak grał z Witkacym, choć w drugim spektaklu Teatru Śmierci - Wielopole, Wielopole - upatrywano kontynuacji tradycji nie tylko Dziadów i Wesela, ale i Ślubu Gombrowicza. Krakowski twórca, jak pisała Katarzyna Fazan, „zacierał wszelkie podobieństwa do funkcji Henryka ze Ślubu, swoistego alter ego Gombrowicza, wchodząc w intensywną relację ze strukturą tego dramatu traktowaną jak palimpsest"».

Inspiracje Tadeusza Kantora prozą Schulza są widoczne w różnych jego spektaklach. Podobnie jednak jak z Gombrowiczem, twórca nigdy nie sięgnął po jeden konkretny tekst i nie zrealizował go na scenie swojego teatru. Fragmenty nowel Schulza pod tytułem Sanatorium pod Klepsydra miały zostać przez niego wystawione w Teatrze Bagatela najprawdopodobniej w 1973 roku. Jednak i do tej premiery nie doszło.

Dziełem, w którym spotkali się Witkacy, Gombrowicz i Schulz, jest niewątpliwie Umarła klasa. W spektaklu rozpoczynającym cykl Teatru Śmierci można znaleźć bardziej lub mniej oczywiste odniesienia do twórczości tych trzech autorów. Najłatwiej dostrzec Witkacego. Kantor wykorzystał bowiem fragmenty Tumora Mózgowicza, odrywając je, zgodnie z własną praktyką, od fabuły dramatu, nadając im nowy kontekst, rozkładając semantycznie krótkie fragmenty dialogów. W partyturze do spektaklu pisał, że w jego dziele dochodzi do spotkania ze sztuką Witkacego' ${ }^{9}$. Przed premierą, w prasie podawał, że nie ma dramatu, na którym opiera swoje przedstawienie: „jest moja realność artystyczna plus koneksje, tradycyjne dla mnie literacko, to znaczy Witkiewicz, Schulz, Gombrowicz"10. W programie do pierwszej wersji

7 Zob. J. Jarzębski, Gombrowicz, Wrocław 2004, s. 139.

8 K. Fazan, Kantor. Nie/Obecność, Kraków 2019, s. 495.

9 T. Kantor, Umarła klasa (Partytura), [w:] idem, Teatr Śmierci..., s. 93.

${ }_{10}$ Zob. K. Fazan, op. cit., s. 488. 
spektaklu zanotował, że uczestnikami seansu są Witkacy i Schulz. Pominął Gombrowicza. Być może przemilczenie autora Kosmosu było związane z biografią pisarza ${ }^{11}$. Witkacy, jak wiemy, popełnił samobójstwo po wkroczeniu do Polski Armii Czerwonej we wrześniu 1939 roku, Schulz został rozstrzelony przez gestapowca na ulicy Drohobycza. Gombrowicz od końca sierpnia 1939 roku był na emigracji w Argentynie.

W eseju należącym już dzisiaj do klasyki krytyki teatralnej $M y$, umarli Konstanty Puzyna przekonywał, że Umarła klasa wzięła się z inspiracji Schulzowskiej, z opowiadania Emeryt. Choć nie było w niej, zdaniem krytyka, ani jednego fragmentu z prozy pisarza ${ }^{12}$, to jednak zarówno manekiny, cheder, szkoła galicyjska, postaci, klepsydry, książki, rupiecie, ciasna przestrzeń zorganizowana w kącie wywodziły się bezpośrednio z tamtego świata. Od Schulza wyprowadzono też aluzje erotyczne czy „ciemną strefę psychoanalitycznych i psychospołecznych insynuacji”. Puzyna podkreślał jednak, że Kantor nie powielał, lecz dzięki Schulzowi odkrywał: „To najgłębiej osobisty jego spektakl. Jakby dopiero Schulz wydobył z jego nieświadomości sfery najbardziej własne, nie znane dotąd jemu i nam - sfery, których nigdy nie wyzwolił z niego Witkacy"13.

Badacze, przejmując ustalenia Puzyny, pozostają jednak zwykle na poziomie ogólności. Choć powstało wiele opracowań pierwszego spektaklu Teatru Śmierci, a związki Kantora z Schulzem są już opisane ${ }^{14}$, to nie trafiłam na analizę Umarłej klasy, która odpowiadałaby na pytania o konkretne wpływy z Emeryta: czy bohatera Schulza da się odnaleźć w którymś ze zdziecinniałych staruszków Umarłej klasy? Które konkretnie fragmenty opowiadania zostały wykorzystane przez Kantora? Czym różni się ujęcie śmierci w opowiadaniu i w spektaklu? Jakimi strategiami posłużył się twórca jako adaptator nieteatralnej prozy? A wreszcie: dlaczego po młodzieńczej fa-

11 Taką hipotezę stawia m.in. Krzysztof Pleśniarowicz. Zob. K. Pleśniarowicz, Kantor, s. 233.

12 Jan Ciechowicz przekonywał, że użyte w spektaklu łacińskie frazy pochodziły z dwóch opowiadań Schulza: jedna z Mój ojciec wstępuje do strażaków, druga - z Emeryta. Zob. J. Ciechowicz, Bruno Schulz w teatrze, [w:] Teatr pamięci Brunona Schulza, red. J. Ciechowicz, H. Kasjaniuk, Gdynia 1993, s. 116-117.

13 K. Puzyna, My, umarli, [w:] idem, Półmrok, Warszawa 1982, s. 107.

14 N. Király, Schulz i Kantor, [w:] Teatr pamięci Brunona Schulza, op. cit., s. 132-141. 
scynacji Sklepami cynamonowymi Kantor wrócił do prozy Brunona Schulza dopiero jako dojrzały artysta? W dalszej części tego tekstu będę szukała odpowiedzi na te pytania.

Najczęściej w Umarłej klasie interpretatorzy dostrzegają odniesienia do Traktatu o manekinach, wyprowadzając od Schulza zainteresowanie Kantora manekinem, woskową figurą, ich łudzącym podobieństwem do człowieka, a zarazem do umarłego ${ }^{15}$. Sam Kantor w rozmowie z Krzysztofem Miklaszewskim przyznawał się do tego źródła: „Pojawienie się manekina zgadza się z moim coraz mocniejszym przekonaniem [...], że życie można wyrazić w sztuce jedynie przez brak życia, przez odwołanie się do śmierci. Manekin w moim teatrze ma stać się modelem, przez który przechodzi silne odczucie śmierci i kondycji umarłych. Modelem dla żywego akto$\mathrm{ra}^{\prime \prime 16}$. Miklaszewski tę własną, ale wyprowadzoną od Schulza koncepcję nazwał Nowym Traktatem o Manekinach. Wprowadzona do Umarłej klasy wymienność kukły i aktora wskazuje nie tylko na ludzką niepełność i niedostateczność, ale przede wszystkim na chęć przedłużenia „egzystencji w martwym tworze", a zacieranie granicy między życiem i śmiercią ma oswajać lęk przed pustką ${ }^{17}$.

Artystyczna strategia Kantora polegała na odwoływaniu się do obrazów czy atmosfery dzieła innego twórcy, na wykorzystywaniu tylko fragmentów utworu, wybranych motywów, dialogów, pojedynczych zdań. Biorąc impuls od Schulza, budował własną koncepcję manekina, własną wersję realności najniższej rangi. Rację ma Marie-Térèse Vido-Rzewuska, wskazując na zasadnicze różnice w postrzeganiu przez obu twórców np. pokoiku wyobraźni czy ubogiego przedmiotu. Człowiek Schulza rywalizuje z Demiurgiem, a jego przedmioty pobudzają zmysły i uruchamiają wyobraźnię. U Kantora zaś człowiek sięga do resztek cywilizacji, odpadków i poprzez surowy przedmiot

15 Zob. np. R. Solewski, Dziedzictwo i tożsamość w twórczości Tadeusza Kantora, [w:] Dziś. Tadeusz Kantor!... op. cit., s. 353. Te fascynacje Kantor mógł też w jakimś stopniu przejąć od Maeterlincka. Zob. K. Czerska, Tadeusz Kantor i Maurice Maeterlinck. Dramaturgie istnienia, Kraków 2019.

16 Zob. K. Miklaszewski, Spotkania z Tadeuszem Kantorem, Kraków 1992, s. 40.

17 W. Owczarski, Miejsca wspólne, miejsca własne. O wyobraźni Leśmiana, Schulza i Kantora, Gdańsk 2006, s. 36-49. Zob. zwłaszcza rozdział Traktat o manekinach. 
uruchamia pamięć i wywołuje wzruszenie ${ }^{18}$. Niewątpliwie jednak Kantor przyznawał się, że zapożyczył termin „najniższa ranga” od autora Sklepów cynamonowych ${ }^{19}$.

Bruno Schulz sformułował pojęcie realności zdegradowanej i w latach 60. stworzyłem sobie taki termin realności najniższej rangi, przy czym do tej „realności najniższej rangi" doszedłem inną drogą. Zapomnieliśmy w tym czasie o Schulzu, ponieważ bardziej aktualny był Witkacy. Wyeksploatowałem już w pewnym sensie Witkacego i dziś bardziej aktualny jest dla mnie Bruno Schulz i w jakimś sensie Gombrowicz. Widoczne to jest w Umarłej klasie ${ }^{20}$.

Atrapa, tandeta, bieda to pojęcia używane przez Schulza, ważne w praktyce i myśli Kantora. U obu twórców osadzone jednak w innym świecie, $\mathrm{w}$ innych barwach. Schulz-pisarz uznawany jest za wybitnego kolorystę. W świecie kolorów prozaika panuje doskonały ład ${ }^{21}$. Rozbuchana materia Schulza jest barwna, choć w Emerycie nie tak bardzo, jak np. w Sierpniu czy Wiośnie. Mimo to autor operuje szeroką skalą kolorów. W jeden z opisywanych przez emerytowanego radcę dni jesiennych „niebo bez słońca ułożyło się w kolorowe smugi, łagodne warstwy kobaltu, grynszpanu i seledynu, zamknięte na samej krawędzi smugą czystej jak woda białości”, a w dniu, w którym wiatr porwał radcę, przestworza były żółte. Świat sceniczny Kantora jest achromatyczny, mieści się w czerni, bieli, ewentualnie sepii ${ }^{22}$.

Inspiracje do przygotowania spektaklu, który rozgrywa się w porzuconej klasie szkolnej, przyniosły zarówno literatura, jak i życie. Początki

${ }_{18}$ M-T. Vido-Rzewuska, Kantor, Schulz, Malczewski, Wyspiański: kilka paradoksów, [w:] Dziś. Tadeusz Kantor!..., op. cit., s. 317-321. Na temat Kantorowskich przedmiotów zob. K. Flader-Rzeszowska, Przedmioty graniczne w Teatrze Śmierci Tadeusza Kantora, „Konteksty. Polska Sztuka Ludowa” 2015, nr 1-2, s. 178-187.

19 Zob. Z. Taranienko, Rozmowy o teatrze, Warszawa 1981, s. 68. O wpływie Schulza na ideę realności najniższej rangi Kantora pisał też Artur Sandauer w eseju Sztuka po końcu sztuki, „Dialog” 1981, nr 3, s. 111.

20 T. Kantor, Moja droga do Teatru Śmierci, [w:] idem, op. cit., s. 457.

${ }^{21}$ M. Kujawski, Znaczenie barw w prozie Brunona Schulza, „Słupskie Prace Humanistyczne" 1990, nr 10a, s. 47.

22 P. Paziński, Atrapy stworzenia, Kraków-Budapeszt-Syrakuzy 2020. Zob. zwłaszcza rozdział Drewno, płótno, wosk. 
Teatru Śmierci dostrzec można już w okupacyjnym Teatrze Niezależnym, gdzie niemożliwy był powrót Odysa do porzuconej niegdyś ojczyzny, gdzie Balladyna związana była $\mathrm{z}$ tronem-sarkofagiem, a postaci poruszały się w korowodowym tańcu. Także w Teatrze Zerowym czy Teatrze Niemożliwym pojawiają się zapowiedzi Teatru Śmierci. Rzeczywisty widok starej klasy szkolnej w Bielkowie, podejrzanej przez okno kilka lat przed premierą, uruchomił w Kantorze skojarzenia, zatarte obrazy, echa słów. Artysta zaczął myśleć o roli wspomnienia, a zarazem o niemożności powołania do życia nieżyjących postaci historycznych czy literackich, niemożności cofnięcia się do czasów dzieciństwa. I tu znowu Kantor i Schulz stają się sobie bliscy. W znanym liście Schulza do Andrzeja Pieśniewicza pisarz wyznawał:

Gdyby można było uwstecznić rozwój, osiągnąc jakąś okrężną drogą powtórne dzieciństwo, jeszcze raz mieć jego pełnię i bezmiar - to byłoby to ziszczeniem „genialnej epoki”, „czasów mesjaszowych”, które nam przez wszystkie mitologie są przyrzeczone i zaprzysiężone. Moim ideałem jest „dojrzeć" do dzieciństwa. To by dopiero była prawdziwa dojrzałość23.

Temat dzieciństwa jest tylko jednym z tych, które łączą twórców. Zdaniem Luigiego Marinellego można wskazać na co najmniej cztery główne pola tematyczno-symboliczne zbieżne dla Schulza i Kantora ${ }^{24}$. To właśnie temat dzieciństwa; pokoju, domu, miasteczka; materii i pamięci oraz twórczości jako „grzesznych manipulacji” (Schulz) i daremnych powtarzań (Kantor).

\section{SPEKTAKL Z SCHULZA}

Umarła klasa powstała w 1975 roku, grana była siedemnaście lat, sześćset razy, miała co najmniej trzy wersje $e^{25}$. Do 1977 roku Kantor grał ją z aktorami Teatru Bagatela. Ta właśnie wersja została sfilmowana przez Andrzeja

${ }^{23}$ List Brunona Schulza do Andrzeja Pleśniewicza z marca 1936 roku, cyt. za: J. Jarzębski, Schulz, Wrocław 1999, s. 57.

${ }^{24}$ L. Marinelli, Kantor w cieniu Schulza, [w:] W ułamkach zwierciadła... Bruno Schulz w 110 rocznicę urodzin i 60 rocznicę śmierci, red. M. Kitowska-Łysiak, W. Panas, Lublin 2003, s. 419.

25 Zob. K. Pleśniarowicz, Kantor, op. cit., s. 229. 
Wajdę i do niej będę się odwoływać ${ }^{26}$. Ale spektakl ten wystawiany był do końca życia Kantora, a nawet jeszcze po jego śmierci, przekroczył nie tylko granice Polski, ale i Europy. Stał się dziełem o światowej sławie, wzruszającym i uruchamiającym tragiczne klisze pamięci pod różnymi szerokościami geograficznymi.

Obraz szkolnej klasy z rozbrykanymi uczniami robiącymi miny, jąkającymi się przy odpowiedziach, z niepanującym nad nimi profesorem natychmiast przywołuje Ferdydurke z niedojrzałym Józiem, Syfonem, Miętusem i profesorem Pimką. Ale widok staruszków-uczniów kieruje też do świata Schulzowskiego Emeryta. Opowiadanie to najprawdopodobniej powstało już w latach dwudziestych, po raz pierwszy zaś zostało wydrukowane w „Wiadomościach Literackich” w 1935 roku. Bruno Schulz zamieścił je potem w tomie Sanatorium pod Klepsydrq ${ }^{27}$. Nie jest to jednak, w przeciwieństwie do innych tytułów, utwór często przystosowywany na scenę. Dopiero wiele lat po Umarłej klasie opowiadanie to stało się podstawą spektaklu telewizyjnego w reżyserii Waldemara Śmigasiewicza. W roli tytułowej wystąpił Jan Peszek. Śmigasiewicz przeniósł prozatorski tekst niemal bez żadnych zmian, cięć i przestawieńn ${ }^{28}$.

26 T. Kantor, Umarła klasa, realizacja: Andrzej Wajda, zdjęcia: Edward Kłosiński, Janusz Kaliciński, Zespół Filmowy X, 1976.

27 Hasło 'Emeryt', oprac. S. Rosiek, [w:] Słownik schulzowski, oprac. i red. W. Bolecki, J. Jarzębski, S. Rosiek, Gdańsk 2006, s. 106.

28 Pozbawiona dialogów i linearnej fabuły proza Schulza dość często jednak trafia na teatralne deski. Adaptowano ją w Polsce kilkudziesięciokrotnie, szukając różnych dróg przekładu, wybierając poszczególne opowiadania bądź mierząc się z całym dziełem, stawiając akcent na różne problemy i motywy. Także forma, w którą wkładano utwory drohobyckiego pisarza, była bardzo różnorodna. Halina Słojewska w monodramie Boczne odnogi czasu (1968) postawiła na teatr opowiadania, z najważniejszą rolą tekstu, a w tym samym czasie Jerzy Kubicki pokazał mimodram Sanatorium pod Klepsydrą. Zbigniew Rudziński w 1981 roku przygotował operę Manekiny. Rudolf Zioło w Teatrze Starym wyreżyserował Republikę marzeń (1987), przybliżając Schulzowską mitologię dzieciństwa z różnych dzieł pisarza. Krakowski Teatr Mandala zaproponował z kolei dwudziestoczterogodzinny projekt $S c h u l z$ wpisany w scenerię Kazimierza, wykorzystując szczątki Schulzowskich opowiadań, stawiając na aktorską improwizację i współudział widzów. Patrząc na te przykłady, widzimy, że teatr zwykle szukał własnych, oryginalnych dróg czytania i wystawiania Schulza. Zob. hasło 'Teatralne 
Na jakich więc zasadach funkcjonował Schulz w Umarłej klasie? Jak pisał Puzyna, Kantor wyciągnął z Emeryta obrazy, przestrzeń, postaci, przedmioty i wykorzystał je na prawie scenicznego recyklingu we własnym dziele $^{29}$. Sądzę, że równie bliskie, co poetyka i estetyka pisarza, były mu także odczucia towarzyszące Schulzowi przy pisaniu opowiadania. W liście do Romany Halpern - adresatki największej zachowanej korespondencji pisarza - Schulz wyznawał: „Mam ludzką obawę przed samotnością, przed tą jałowizną życia niepotrzebnego i zamarginesowego, którą chciałem oddać w Emerycie". Kantor, przygotowując Umarła klasę, miał sześćdziesiąt lat. Temat jałowego życia, samotności, przemijania coraz częściej wychylał się $\mathrm{z}$ jego dzieła. W znanym Małym manifeście, pisanym trzy lata po premierze Umarłej klasy, wyznawał: „To nieprawda, że człowiek nowoczesny to umysł, który zwyciężył lęk. Nie wierzcie. Lęk istnieje. Lęk przed światem zewnętrznym, lęk przed losem, przed śmiercią, lęk przed nieznanym, przed nicością, przed pustką"30.

Mimo iż koneksje Schulzowskie są w Umarłej klasie wyraźne, nie można widzieć w Kantorze klasycznego adaptatora. Adaptacja teatralna (adaptare przystosowywać) epiki wiąże się z rozpisaniem narracji na działania sceniczne i dialog, a następnie dąży - na różne sposoby - do przystosowania scenicznego utworu. Patrice Pavis wymienia różne zabiegi, które może stosować adaptator. Mieszczą się tu: skróty, cięcia, reorganizacja fabuły, redukcja postaci czy miejsc akcji, koncentracja fabuły, włączanie tekstów dodatkowych (montaż) czy modyfikacja zakończenia ${ }^{31}$. Najczęściej spotykamy

adaptacje twórczości Schulza', oprac. J. Jarzębski, [w:] Słownik schulzowski, op. cit., s. 383-393. O adaptacjach prozy Schulza pisał też Jan Ciechowicz w cytowanym już artykule Bruno Schulz w teatrze.

${ }_{29}$ Według Vido-Rzewuskiej Kantor przywłaszczał i zniekształcał m.in. dzieła Schulza. Zob. Kantor, Schulz, Malczewski, Wyspiański: kilka paradoksów, [w:] Dziś! Tadeusz Kantor..., op. cit., s. 317. Jan Kłossowicz przekonywał, że Kantor nie rezygnując z literatury, traktował ją jako objet trouvé. Zob. J. Kłossowicz, Tadeusz Kantor. Teatr, Warszawa 1991, s. 59.

30 T. Kantor, Mały manifest, [w:] idem, Teatr Śmierci..., op. cit. Teksty z lat 1975-1984 , op. cit., s. 23.

${ }_{31}$ P. Pavis, hasło 'adaptacja', [w:] idem, Słownik terminów teatralnych, tłum. i oprac. S. Świontek, Wrocław 2002, s. 21-22. 
się z trzema metodami adaptacji tekstów niedramatycznych: dostosowanie tekstu oryginalnego na scenę, adaptacja tekstu oryginalnego do potrzeb sceny i tworzenie nowego tekstu inspirującego się literackim oryginałem ${ }^{32}-$ Kantorowi te zabiegi były zupełnie obce. Ironicznie podkreślał, że tekst literacki jest na scenie reprodukowany, ilustrowany albo interpretowany ${ }^{33}$. Żadna z tych kategorii nie mieściła się w jego słowniku. Nie interesowało go streszczanie dzieła, przemontowywanie jego struktury, nie chciał transponować go na scenę ani go komentować. Redukcja, inwersja, transakcentacja to różne, ale wciąż dążące do otwierania i odczytywania tekstu na scenie, sposoby, które Kantor uznawał za bezcelowe i nietwórcze. Przygotowując Umarłą klasę, wciąż - jak w Witkacowskich spektaklach - zestawiał dwie rzeczywistości, dwa tory: autonomiczną, wolną, realną rzeczywistość sceny i fikcyjną, imaginacyjną, mocno pociętą strukturę pisarskiego dzieła. Jak mawiał, realność Umarłej klasy czasem wślizgiwała się w sferę sztuki, umarli staruszkowie podszywali się pod Witkacowskie, Schulzowskie czy Gombrowiczowskie postaci. Chodziło jednak przede wszystkim o ocalenie autonomii teatru.

Zgodnie z definicją Dariusza Kosińskiego, adaptator zwykle „zachowuje najważniejsze elementy świata przedstawionego w adaptowanym dziele i ogranicza własną interpretację do minimum", wybiera najchętniej powieści o dynamicznej akcji z jasno zarysowanymi postaciami ${ }^{34}$. Kantor na plan pierwszy wysuwał własne dzieło sceniczne, a nie jego literacką podstawę. Przekładał narrację Emeryta nie na dialogi, lecz na obrazy. A raczej przejmował Schulzowskie obrazy i ukradkiem wprowadzał je do własnego świata realności najniższej rangi. Nie sięgnął po wartką powieść, lecz prawie pozbawione dialogów opowiadanie z jedną główną postacią. W Cricot 2 akcja

${ }^{32}$ Zob. M. Miłoszewska, Skrzynka z narzędziami. Podręcznik dramaturgiczny, Warszawa 2017. Jan Ciechowicz, posługując się typologią wypracowaną przez Dostojewskiego, wymieniał także trzy główne zabiegi adaptacyjne: skrócona wersja prozy, czyli adaptacja właściwa, dramatyzacja wybranych epizodów, wreszcie tworzenie samodzielnego dramatu na podstawie prozy, który zawdzięcza pierwowzorowi ideę. Zob. J. Ciechowicz, Bruno Schulz w teatrze, op. cit. s. 112.

33 T. Kantor, Umarła klasa (Partytura), [w:] idem, Teatr Śmierci..., s. 159.

34 D. Kosiński, hasło 'adaptacja teatralna', [w:] idem, Słownik teatru, Kraków 2009, s. 11. 
składała się z „łańcucha sekwencji, które nie stanowią żadnego ciągu fabularnego, treściowo odizolowane, istniejące same dla siebie" ${ }^{35}$. Sąsiadowanie ze sobą poszczególnych scen było nieraz absurdalne. Jedyne, co miało je łączyć, to napięcie. Dla Kantora spektakl był układem napięć dynamicznych, które często powstawały dzięki stosowanym kontrastom i szokującym zestawieniom. Widz miał nie tyle uczestniczyć w intelektualnej przygodzie, co doświadczyć siły emocji. „Byłoby nierozsądną pedanterią bibliofila ostrzegał Kantor - starać się znaleźć owe brakujące fragmenty dla pełnej "wiedzy« o przedmiocie fabuły sztuki" ${ }^{36}$. Kiedy Kantor miał przedłożyć tekst Umarłej klasy w urzędzie cenzury, nie dysponował tradycyjnym scenariuszem. Miał zebrane cytaty z Biblii, fragmenty z Witkacego, kilka fraz z chederu, piosenki. Na poziomie tekstu literackiego rzeczywiście było to tylko tyle, na poziomie obrazu, nastroju, aury świata przedstawionego zdecydowanie więcej. Jak podkreślała Maria Stangret, Kantor nie pisał scenariuszy z wyznaczonymi zachowaniami i działaniami, lecz partytury, które powstawały najczęściej post factum. Powiązanie z terminologią muzyczną było jej zdaniem celowe i zasadne: „aktor w Cricocie funkcjonował trochę na podobieństwo muzyka w orkiestrze, której dyrygentem był zarazem autor utworu" 37 .

Pracę Kantora nad tekstem można nazwać strategią resztek. Twórca Teatru Śmierci pozwalał objawić się na scenie tylko porwanym fragmentom akcji, oderwanym od siebie sytuacjom, wypadkom, działaniom, resztkom mowy, ruchu. Przekonywał bowiem, że do czasu teraźniejszego z przeszłości docierają tylko resztki. Chcąc przywołać na scenie wspomnienia, można odwoływać się tylko do śladów, fragmentów, powidoków. Kantor sięgał do pamięci emocjonalnej, która swym przedmiotem czyni nie akcję, lecz obrazy ${ }^{38}$. W Umarłej klasie pojawiły się zarówno resztki wspomnień, obrazów z dzieciństwa, resztki historii prywatnej i tej powszechnej, a także resztki z lektur młodości. Jerzy Jarzębski mówił o wykorzystywaniu wątków

35 T. Kantor, op. cit., s. 159.

36 T. Kantor, Ostrzeżenia, [w:] idem, Teatr Śmierci..., s. 32.

37 M. Stangret, „Nadobnisie i koczkodany” i „Umarła klasa”, „Konteksty. Polska Sztuka Ludowa” 2015, nr 1-2, s. 93.

38 Zob. E. Rewers, Więcej pamięci. Ku transkulturowości, [w:] idem, Post-Polis. Wstęp do filozofii ponowoczesnego miasta, Kraków 2005, s. 184. 
Gombrowiczowskich, a Krzysztof Pleśniarowicz o „językowych cytatach i wizualnych echach" z Tumora Mózgowicza, prozy Schulza i z Ferdydurke $e^{39}$.

To była jedna z zasad Teatru Śmierci: podejmowane i porzucane literackie role czy motywy uniemożliwiały ponowne narodziny postaci i zdarzeń już dawno umarłych. W rytmie skupienia i rozproszenia powracały i niknęły obrazy to Gombrowiczowskiej, to znów Schulzowskiej szkoły, napiętnowane późniejszym doświadczeniem Holocaustu ${ }^{40}$.

Choć rzeczywistość sceny była zawsze dla Kantora „materią pierwszą”, to twórca nie rezygnował jednak całkiem z literatury. Traktował ją jak jeden z elementów teatru. Także w ostatnich cricotage’ach wykorzystywał fragmenty Biblii (Cicha noc) czy wiersz Rimbauda Śpiący w dolinie (Bardzo krótka lekcja). W Mojej drodze do Teatru Śmierci czytamy: „nigdy nie pozwalałem sobie na to, żeby zupełnie zlikwidować tekst literacki, tak jak to robi wielu reżyserów współczesnych, którzy uważają, że tekst literacki pisze się na scenie $\mathrm{w}$ czasie prób albo się zupełnie $\mathrm{z}$ tekstu rezygnuje. Twierdzę, że w ten sposób teatr schodzi na teren baletu i pantomimy i nie jest już teatrem dramatycznym"41.

\section{EMERYT Z PIERWSZEJ ŁAWKI}

Przyjrzyjmy się zatem, co konkretnie i w jakim stopniu Kantor zaczerpnął z tekstu literackiego Schulza. Przestrzenią, w której dzieje się znaczna część opowiadania, jest szkolna klasa, w której odbywają się lekcje gramatyki, sylabizowania, tabliczki mnożenia. Występujące postaci to, oprócz urzędników, szkolny dozorca, uczniowie i profesor. Bohater Schulza - emeryt, który przekroczył już być może „pewne ostateczne i dopuszczalne granice” - jako weteran abecadła powraca do szkolnej klasy. Choć jest niepewny w nogach, odczuwa niezwykłą muzykalność członków i poddaje się upartemu rytmowi słyszanych melodii: „Więc tańczę, a raczej drepcę w takt melodii drobnym truchcikiem emerytów, podskakując od czasu do czasu”"42. Przyglądając

39 K. Pleśniarowicz, op. cit., s. 231.

40 Ibidem.

${ }_{41}$ T. Kantor, Moja droga do Teatru Śmierci, [w:] idem, Teatr Śmierci..., s. 459.

42 B. Schulz, Emeryt, [w:] idem, Sklepy cynamonowe, Sanatorium pod Klepsydra, Warszawa 2000, s. 321. 
się scenom spektaklu Kantora, można dostrzec podobną choreografię. Staruszkowie „podrygują jak manekiny.../ stawiają nogi, poruszają rękami, prostują głowy, wypinają piersi.../ ostentacyjnie, aby udowodnić, że jeszcze żyją!"’3. Dreptanina w takt melodii popularnego Walca François (kompozycja Zygmunta Karasińskiego) ${ }^{44}$ stanowi jeden z namolnie powtarzających się obrazów i rytmów. Twórczość Schulza i Kantora łączy kategoria muzyczności. U obu zaobserwować można muzyczne figury: powtarzalność elementów, zmianę sposobu ich prezentacji, czyli „falowanie”, polifoniczność polegającą na wielości elementów, współbrzmienie oparte na zestawieniu różnych zjawisk oraz grę stłumień i wzmocnień ${ }^{45}$. Kantor był dramaturgiem dźwięku, budował orkiestrację spektaklu, architektonikę muzyczną dzieł ${ }^{46}$. Miał świetny słuch. Jego wybory muzyczne nie były jednak mocno wysublimowane. Zawsze stawiał na znane motywy muzyczne, które przekształcał, wykorzystywał fragmentarycznie, powtarzał wielokrotnie, by budowały niepokój i wzruszenie. Dźwięki rosnąc i niespodziewanie opadając, tłumiły i wzmacniały emocjonalne napięcie widzów: „Ten sentymentalny i szalenie banalny walc - przestaje być banalny przez to, że wyjąłem tylko bardzo malutką frazę i poddałem to nieustającej repetycji”. Pow tórzenia - nie tylko muzyczne - budowały rytm spektaklu, zwiększały ekspresję, tworzyły mit.

Przywołaną z pamięci Kantora dawną klasę zaludniają staruszkowie-uczniowie połączeni z manekinami dzieci, odbywający lekcje łaciny czy gramatyki. Nieudolnie sylabizują, powtarzają mechanicznie wtłaczany materiał, przywołują kulturowych bohaterów, fragmenty znanych powiedzeń, które zaraz przecinają dziecięcymi wyliczankami. „Majaczenia historyczne” (np.

43 T. Kantor, Umarła klasa (Partytura), [w:] idem, Teatr śmierci..., s. 53.

${ }^{44}$ Maria Stangret wspominała, że Kantor pierwszy raz usłyszał melodię Walca w kawiarni przy ulicy Szczepańskiej: „Cichutko zaśpiewałam znany mi fragment refrenu Gdyby jeszcze raz wrócił piękny czas... Tadeusz spojrzał na mnie uważnie i poprosił, bym jeszcze raz zanuciła. Potem wstał i rozpromieniony zawołał: »Mam muzykę do Umarłej klasy«. Byłam zaskoczona, bo nigdy nie domyśliłabym się, że ta sentymentalna melodia będzie zdolna potęgować taką grozę w przedstawieniu. Tymczasem on to już zobaczył w swej wyobraźni, w tej kawiarni”. Zob. M. Stangret, op. cit., s. 92.

${ }^{45}$ Hasło 'muzyczność', oprac. W. Bolecki, [w:] Słownik schulzowski, op. cit., s. 232.

${ }^{46}$ K. Czerska, Muzyczność teatru Kantora, [w:] idem, op. cit., s. 157-189. 
„kości zostały rzucone”) były często cytatami z Sanatorium pod Klepsydrą ${ }^{47}$. Staruszkowie, jak emeryt, są weteranami abecadła. Klasy pilnuje pedel szkolny dozorca. Schulzowski emeryt wracając do pierwszej klasy, był zagubiony, podtrzymywał się połów dyrektora, który wpychał go do pierwszej ławki. O tym, że emerytowany radca bliski był Kantorowi, może świadczyć ponownie fragment Małego manifestu: „Stoję przed wami, jak dawniej... stałem w ławce... w klasie szkolnej... i mówię: ja zapomniałem, ja wiedziałem, wiedziałem na pewno, zapewniam Was, Panie i Panowie..." ${ }^{\prime 4}$. W Kantorowskiej klasie na przodzie zasiada Staruszek Nieobecny z Pierwszej Ławki grany przez Lilę Krasicką. Można dostrzec w nim Schulzowskiego radcę, a w jakimś stopniu samego Kantora. Mocna charakteryzacja sytuuje go po stronie śmierci. Trudno stwierdzić, czy to trup czy zdziecinniały staruszek u kresu życia. Pasuje do Schulzowskiego opisu, w którym czytamy: „sztywność maski odzwyczajonej od ruchów mimicznych"49. Sam Kantor określał tę postać jako najbardziej dotkniętą śmiercią. Staruszek Nieobecny z Pierwszej Ławki z utkwionym $\mathrm{w}$ jednym punkcie wzrokiem nie jest samodzielny, wymaga podtrzymywania i prowadzenia, nie wie, że trzeba wstać, że należy wyjść. Jest całkowicie bezwładny i zagubiony. Trafia, jak emerytowany radca, w środek uczniowskich zgryw i harców. Sam jednak w nich nie uczestniczy. Przynależy do innego porządku. Nie da się bowiem powrócić do dzieciństwa. Bohaterowie Umarkej klasy, jak emeryt czy Józio, jąkają się i powtarzają zadawane przez profesora pytania, niezdarnie szukają odpowiedzi, uczestniczą w nudnym przepytywaniu ze słówek i deklinacji. Ale zarazem uosabiają rzeczywistość sprzed Wielkiej Wojny, a potem sprzed Zagłady. Za sprawą literackich strzępków, wizualnych ech, muzycznych cytatów przywołują utracony wielokulturowy świat charakterystyczny zarówno dla Wielopola Skrzyńskiego Kantora, jak i Drohobycza Schulza ${ }^{50}$. Ich wspomnienia są traumatyczne, bolesne, wspomnienia emeryta - przyjemne,

${ }_{47}$ Zob. T. Kantor, op. cit., s 70.

48 T. Kantor, Maty manifest, [w:] idem, op. cit., s. 23.

49 B. Schulz, Emeryt, [w:] idem, op. cit., s. 319.

50 O małych ojczyznach obu twórców powstało dość dużo prac. Można wspomnieć m.in. publikację Klaudiusza Święcickiego Małe ojczyzny Europy w teatrze Tadeusza Kantora (Kraków 2002) czy biografię Anny Kaszuby-Dębskiej Bruno. Epoka genialna (Kraków 2020). 
sentymentalne. Bohaterowie Kantora przeżyli więcej niż radca, zajrzeli za kolejny historyczny horyzont. Grzegorz Niziołek przekonywał, że Kantor stosował strategie wymazywania: „z kliszami przeszłości grał od zawsze, wprowadzał je obficie także w swoje przedstawienia witkacowskie, ale uniemożliwiał ich odczytanie, uruchamiał niezwykle skuteczne mechanizmy samowymazywania się sensów. To co realne, czuwało u Kantora nad paraliżem zdolności symbolicznych"51. Tak została też skonstruowana Umarła klasa, ale spektakl pomyślany jako miejsce „rozpadu symbolicznego porządku, emanacja czystego lęku, został przeniesiony za sprawą widowni w obszar przestrzeni symbolicznej"52. Wymazywanie Kantora było nieskuteczne. A może miało być nieskuteczne? Świat Schulzowskiej klasy stał się popiołem.

Zapożyczając obraz uczniowskiej walki na miny zarówno z Emeryta, jak i z Ferdydurke, Kantor także w teorii rozważał problem miny i gęby, czyniąc go przedmiotem uwag w Partyturze spektaklu. Uważał, że mina jest „skuteczną bronią niedojrzałości przeciw »powadze« dorosłych, która najczęściej maskuje ich brak wrażliwości, czułości, wyobraźni, bezwzględność, okrucieństwo, obłudę, pustkę... [...] zdziera bezlitośnie obojętną oficjalną maskę, dobiera się do wnętrza, ukrywanego przezornie" ${ }^{53}$. Maska mimiczna kończy się jednak wraz ze śmiercią, gdy zastyga w maskę pozbawioną życia; to wspomnienie o tym, czym twarz kiedyś była. Staruszek Nieobecny z Pierwszej Ławki ma właśnie nieruchomą twarz-maskę. W notatniku reżyserskim Kantor zapisywał, że bezbronna, wystawiona na zniewagi ekspresyjna twarz aktora nie należy do niego, lecz do widza, jest własnością drugiego. Sprzeciwiał się kształtowaniu człowieka beznamiętnego, o anonimowej twarzy kultury masowej. Kantor walczył jednak z przyprawianiem gęby. Sam, jak przekonywała Katarzyna Fazan, musiał wyrywać się „gębie”.

Kantor z punktu widzenia totalitaryzmów - nigdy nie miał „dobrej twarzy”. Jego fizjonomia mogła budzić wątpliwości i za okupacji, i w kontekście socrealistycznych przewartościowań. Jego oblicze zawsze wyróżniało się, było wyraziste, a nie pospolite, uderzało inteligenckim wyrazem, odznaczało się osobliwą, groteskową mimiką. Było poważne i zabawne, dojrzałe i szlachetne, a zarazem niedorosłe i niezdyscyplinowane. Skutecznie wymykało się idei

${ }^{51}$ G. Niziołek, Polski teatr Zagłady, Warszawa 2013, s. 414.

52 Ibidem.

53 T. Kantor, Umarta klasa..., op. cit. s. 79. 
„gęby”, pojęciu Gombrowicza, bliskiemu Kantorowi szczególnie w czasie pracy nad Umarła klasa ${ }^{54}$.

Podczas gdy uczniowie walczą na miny, przyprawiają sobie gęby, Staruszek Nieobecny z Pierwszej Ławki wciąż pozostaje nieruchomy. Włącza się do akcji dopiero wtedy, kiedy staruszkowie stają się postaciami z Tumora Mózgowicza. Wówczas, jak inni uczniowie, ucieka przed zbierającą żniwo śmiercią, pada martwy, a potem wraca do ławki w rytm stukających o kołyskę kul ${ }^{55}$. Kiedy rozmywa się akcja Tumora, a powraca realność klasy szkolnej, Staruszek Nieobecny na nowo staje się zastygłym w pierwszej ławce uczniem. Nie szuka odpowiedzi na pytania o piętę Achillesa czy pępek świata, nie wpada w rytmiczne zawodzenie „rodem $z$ chederu” ani nie podnosi się na dźwięk walca. Dopiero kiedy Kobieta za Oknem zachęca, by dzieci poszły się przejść, samodzielnie podnosi się i drepcąc w rytm piosenki, krąży wokół ławek. Jego twarz staje się polem walki ruchomej i zastygłej maski, życia i śmierci. Zastanawiające, że Kantor nie przydziela mu żadnej kwestii z Tumora Mózgowicza, nie zostaje „zaprogramowany treścią sztuki”, jakby nie przynależał do świata Witkacego, lecz tylko do świata Schulza. Twórca spektaklu pozwala mu powiedzieć jedno samodzielne zdanie - w wersji zarejestrowanej przez Wajdę - prosto do oka kamery. Staruszek Nieobecny z Pierwszej Ławki niskim głosem mówi stanowczo: „Jeszcze chwilę, panie kacie"56; chce wyrwać się z objęć tego, co nieuniknione, wymknąć się spod kosy panoszącej się na scenie Sprzątaczki-śmierci.

Pod koniec opowiadania Schulza, kiedy zrywa się silny wiatr, który niebawem porwie w przestworza radcę, pisarz przywołuje obraz miejskich kominów. To motyw, który uobecni się zarówno w malarstwie, jak i w teatrze Kantora. W 1989 roku powstanie seria złożona z trzech dużych płócien zatytułowana Mój dom. Przedstawia ona rozsypujący się komin podtrzymywany drewnianą podpórką, który na dwóch obrazach wychodzi nie z dachu domu,

54 K. Fazan, op. cit., s. 470.

55 Na temat roli rytmu w Umarłej klasie pisał Krzysztof Pleśniarowicz w Teatrze Śmierci Tadeusza Kantora (Chotomów 1990). Problematykę tę podnosił też Wojciech Owczarski w książce Miejsca wspólne, miejsca własne w rozdziale Rytm jako światopogląd.

56 Tak brzmiały rzekomo ostatnie słowa zgilotynowanej pod koniec XVIII wieku. Madame du Barry - metresy króla Ludwika XV. 
lecz z drewnianej podłogi, jak sugerowała Zofia Gołubiew - może teatralnej sceny lub wnętrza pokoju ${ }^{57}$. Chociaż nie ma domu, a na jednym z obrazów wokół tli się łuna, sugerująca dogasający pożar, to $\mathrm{z}$ komina wydostaje się dym - jest on czynny. Komin stanie się jednym z ważniejszych elementów przestrzeni ostatniego ukończonego spektaklu artysty - cricotage’u Cicha noc. Tylko on ocaleje po katastrofie, po wypalonym świecie, po zburzonym domu ${ }^{58}$. To ostatni, a może pierwszy obraz życia? Schulz i Kantor inaczej jednak widzą śmierć. Dla Schulza nie jest ona czymś definitywnym, nie jest też rytuałem, przejściem, lecz „,rozprężeniem form-masek”, „zatarciem kształtu" danej osoby w pamięci bliskich. Umarli żyją bowiem w pamięci i snach. Żyją też dzięki regresowi do świata dzieciństwa ${ }^{59}$. Radca z Emeryta zostanie porwany przez wichurę i zabrany w przestworza. Czytelnik ma jednak wrażenie, że to porwanie dziejące się na tle barwnej przyrody ma w sobie coś pozytywnego, nawet radosnego. Śmierć emeryta nie jest procesem zamkniętym, nie łączy się z pustym ciałem, rozkładem, grobem.

Postaci Kantora przychodzą z krainy śmierci, mają blade twarze, zniszczone, zbutwiałe garnitury i suknie. Kantor sytuuje je pomiędzy martwotą a rozkładem, pokazuje życie z perspektywy cmentarza. Twórca, jak pisał Jan Kott, staje się jednak pamięcią po miejscach i ludziach: „w tej pamięci jest nie tylko śmierć, lecz także urodziny. Urodziny są zaprzeczeniem śmierci. Pamięć jest zawsze narodzinami. Przywróceniem umarłego żywym"60. Śmierć u Kantora jest rytuałem, jest przejściem ku nieznanemu, niewidzialnemu, tajemniczemu. W tym sensie, wbrew kolorystyce, może nieść nie tylko strach, ale i rodzaj obietnicy. Nieznane wychyla się zza uchylonych drzwi, prześwituje w głębi, po drugiej stronie okna, migoce w jasnym świetle rozbłyskającym gdzieś w oddali.

Chociaż w rozmowie z Aldoną Skibą-Lickel Kantor, pod koniec twórczej drogi, odcinał się od literackich inspiracji, przeczył jakoby kontynuował

57 Z. Gołubiew, „Mam wam coś do powiedzenia”: Tadeusz Kantor-autoportrety, Kraków 2000, s. 42-44.

58 Po drugiej wojnie światowej komin stał się elementem wpisanym w tragiczny obraz Zagłady.

59 Zob. J. Jarzębski, Schulz, op. cit., s. 186-187.

60 J. Kott, Kadysz. Strony o Tadeuszu Kantorze, Gdańsk 2005, s. 38. 
myśl poprzedników, mówił o śladach, a nie wpływach ${ }^{61}$, to jego powrót do porzuconego niegdyś Schulza wydaje się oczywisty. Po latach gier i eksperymentów z Witkacym Kantor znów sięga do bliskiego mu mentalnie drohobyckiego pisarza ${ }^{62}$. Znamienne, że dzieje się to wtedy, kiedy twórca ze względu na wiek zaczyna mocniej odczuwać własne przemijanie i wzmożoną chęć powrotu do dziecięcego świata. Kiedy obawia się śmierci. Pisarz powrotów, pamięci, prywatnych mitologii wydaje się najwłaściwszym partnerem na scenie. Kantor nie nachalnie, lecz wyraźnie odwołał się do Emeryta, zwłaszcza poprzez postać zagubionego Staruszka Nieobecnego z Pierwszej Ławki. Chętnie powraca on do szkoły, jednak potrzebuje ciągłego wsparcia, wepchnięty do pierwszej ławki odcina się od gromady rozkrzyczanych uczniów - jest najbliżej śmierci. Jego podobieństwo z radcą można dostrzec też w sposobie poruszania się i reagowania na muzykę. To ważne, że w roli tej Kantor obsadził Lilę Krasicką, która współpracowała z nim od okupacyjnego Teatru Niezależnego. Można przypuszczać, że jej osoba przenosiła go do czasu młodości, była żywym śladem minionego świata. Można założyć, że podczas pracy nad Umarła klasa bliskie staje się Kantorowi nie tylko opowiadanie Emeryt, ale także znajdująca się w tym samym tomie Samotność, której bohater - też emeryt - nie wiadomo, kiedy i jak trafił na powrót do pokoju dzieciństwa, będącego ostatnią izbą od ganku. Pokoju martwego, wybielonego wapnem, zamurowanego. Czytając notatki Kantora z ostatnich lat życia, odnajdziemy emocje podobne do tych, jakie towarzyszą emerytowi w Samotności:

$\mathrm{W}$ bezsenne noce

cierpienia i rozpaczy [...]

rodzi się stopniowo

samotność.

Wielka.

${ }^{61}$ A. Skiba-Lickel, Aktor według Kantora, Wrocław 1995, s. 30-32.

62 Wojciech Owczarski przekonywał, że relacja Kantora i Witkacego oparta była na wpływie i dominacji, a Kantora i Schulza na pokrewieństwie. Zob. W. Owczarski, op. cit., s. 341 
Nieskończona

i gotowa na

„entrée” śmierci ${ }^{63}$.

\section{Bibliografia}

Wiesław Borowski, Tadeusz Kantor, Wydawnictwa Artystyczne i Filmowe, Warszawa 1982.

Karolina Czerska, Tadeusz Kantor i Maurice Maeterlinck. Dramaturgie istnienia, Wydawnictwo Uniwersytetu Jagiellońskiego, Kraków 2019.

Agnieszka Dauksza, Jaremianka, Znak, Kraków 2019.

Katarzyna Fazan, Kantor. Nie/Obecność, Wydawnictwo UJ, Kraków 2019.

Katarzyna Flader-Rzeszowska, Przedmioty graniczne w Teatrze Śmierci Tadeusza

Kantora, „Konteksty. Polska Sztuka Ludowa” 2015, nr 1-2.

Zofia Gołubiew, „Mam wam coś do powiedzenia” Tadeusz Kantor - autoportrety,

Muzeum Narodowe w Krakowie, Kraków 2000.

Jerzy Jarzębski, Gombrowicz, Wydawnictwo Dolnośląskie, Wrocław 2004.

Jerzy Jarzębski, Schulz, Wydawnictwo Dolnośląskie, Wrocław 1999.

Tadeusz Kantor, Dalej już nic... Teksty z lat 1985-1990, Pisma, tom III, wybór i oprac.

K. Pleśniarowicz, Zakład Narodowy im. Ossolińskich, Ośrodek Dokumentacji

Sztuki Tadeusza Kantora „Cricoteka”, Kraków-Wrocław 2005.

Tadeusz Kantor, Teatr Śmierci. Teksty z lat 1975-1984, Pisma, tom II, wybór i oprac.

K. Pleśniarowicz, Zakład Narodowy im. Ossolińskich, Ośrodek Dokumentacji

Sztuki Tadeusza Kantora „Cricoteka”, Kraków-Wrocław 2004.

Tadeusz Kantor. Wędrówka, red. J. Chrobak, L. Stangret, M. Świca, Cricoteka, Kraków 2000.

Jan Kłossowicz, Tadeusz Kantor. Teatr, PIW, Warszawa 1991.

Dariusz Kosiński, Słownik teatru, Krakowskie Wydawnictwo Naukowe, Kraków 2009. Jan Kott, Kadysz. Strony o Tadeuszu Kantorze, Słowo/obraz terytoria, Gdańsk 2005.

Marek Kujawski, Znaczenie barw w prozie Brunona Schulza, „Słupskie Prace Humanistyczne" 1990, nr 10a.

Krzysztof Miklaszewski, Spotkania z Tadeuszem Kantorem, TKECh Dział Wydawniczy, Kraków 1992.

Marta Miłoszewska, Adaptacja. Skrzynka z narzędziami. Podręcznik dramaturgiczny, Akademia Teatralna im. Aleksandra Zelwerowicza, Warszawa 2017.

Grzegorz Niziołek, Polski teatr Zagłady, Instytut Teatralny im. Zbigniewa Raszewskiego, Wydawnictwo Krytyki Politycznej, Warszawa 2013.

${ }_{63}$ T. Kantor, Ocalić przed zapomnieniem, [w:] idem, Dalej już nic..., s. 129. 
Zbigniew Osiński, Tadeusz Kantor - Jerzy Grotowski: dwie idee teatru/sztuki, [w:] Dziś Tadeusz Kantor. Metamorfozy śmierci, pamięci i obecności, red. M. Bryś, A.R. Burzyńska, K. Fazan, Wydawnictwo Uniwersytetu Jagiellońskiego, Kraków 2014 ,

Wojciech Owczarski, Miejsca wspólne, miejsca własne. O wyobraźni Leśmiana, Schulza i Kantora, słowo/obraz terytoria, Gdańsk 2006.

Patrice Pavis, Słownik terminów teatralnych, tłum. i oprac. S. Świontek, Zakład Narodowy im. Ossolińskich, Wrocław 2002.

Piotr Paziński, Atrapy stworzenia, Wydawnictwo Austeria, Kraków-BudapesztSyrakuzy 2020.

Krzysztof Pleśniarowicz, Kantor, Wielka Litera, Warszawa 2018.

Krzysztof Pleśniarowicz, Teatr Śmierci Tadeusza Kantora, „Verba”, Chotomów 1990 Konstanty Puzyna, Półmrok: felietony teatralne i szkice, PIW, Warszawa 1982.

Artur Sandauer, Sztuka po końcu sztuki, „Dialog” 1981.

Bruno Schulz, Sklepy cynamonowe, Sanatorium pod Klepsydra, Warszawa 2000.

Aldona Skiba-Lickel, Aktor według Kantora, Zakład Narodowy im. Ossolińskich, Wrocław 1995.

Słownik schulzowski, oprac. i red. W. Bolecki, J. Jarzębski, S. Rosiek, słowo/obraz terytoria Gdańsk 2006.

Maria Stangret, „Nadobnisie i koczkodany” i „Umarta klasa”, „Konteksty. Polska Sztuka Ludowa" 2015, nr 1-2.

Zbigniew Taranienko, Rozmowy o teatrze, Centralny Ośrodek Metodyki Upowszechniania Kultury, Warszawa 1981.

Teatr pamięci Brunona Schulza, red. J. Ciechowicz, H. Kasjaniuk, Władze Miasta Gdyni, Gdynia 1993.

W ułamkach zwierciadła... Bruno Schulz w 110 rocznicę urodzin i 60 rocznicę śmierci, red. M. Kitowska-Łysiak, W. Panas, TNKUL, Lublin 2003.

\section{Artistic Reality and Literary Connections. Bruno Schulz in Tadeusz Kantor's The Dead Class}

The inspiration that Tadeusz Kantor drew from the works by Schulz can be seen in many of his theatre performances. Like he did with Gombrowicz, Kantor never used one specific work to be staged in his theatre. The Dead Class is a piece where one can find influences by Witkacy, Gombrowicz and Schulz - probably the three most important writers for Kantor. In this article, I discuss the way Schulz, with his short story A Pensioner, is handled in the 'Cricot 2' performance. Even though many studies concerning this performance have been written and the connections between Kantor and Schulz seem to have been covered, I have not found any study of Dead Class which would indicate any specific references to A Pensioner. In the 
article, the following questions are explored: Can Schulz's protagonist be recognized in the senile, childlike old people from Dead Class? Which passages of the short story were used by Kantor? How differently is the notion of death treated in the short story and in the performance? And finally, why - having been so fascinated with The Cinnamon Shops at a young age - did Kantor come back to Bruno Schulz's writings only as a mature artist? In the article, I also discuss the strategies utilized by Kantor to adapt the non-theatrical prose for the stage.

Keywords: Tadeusz Kantor, Bruno Schulz, Pensioner, Dead Class, Cricot 2, adaptation

Data otrzymania tekstu: 16.03.2021 r.

Data zakończenia procesu recenzyjnego: 15.04.2021 r.

Data akceptacji tekstu do druku: 22.04.2021 r. 
